\title{
Flea beetles (Coleoptera, Chrysomelidae, Halticinae) on rapeseed and sugarbeet in Finland
}

\author{
ARJA AUGUSTIN, ${ }^{1}$ UNTO TULISALO $^{1}$ and SEPPO KORPELA ${ }^{2}$ \\ 1 Öljynpuristamo Oy, SF-00810 HELSINKI, Finland \\ ${ }^{2}$ Agricultural Research Centre, SF-13600 JOKIOINEN, Finland
}

\begin{abstract}
Surveys of the incidence of flea beetles on sugarbeet and rapeseed were carried out in eight localities in southern and central Finland in 1972 and 1980-83. The first flea beetles emerged from overwintering in late April to early May, depending on the temperature. The majority, however, appeared during the second half of May, when daily temperatures occasionally reached $+20^{\circ} \mathrm{C}$. Flea beetles found their host plants by olfactory orientation. Two population peaks occurred during the growing season. The overwintered flea beetles formed the first peak in late May to early June and the adults of the new generation the second peak starting in late July. The incidence of flea beetles fluctuated greatly on the cultivation, as the flea beetles moved only short distances and showed thus very local occurrence. The availability of host plants greatly affected their reproduction rate, and thus the annual and regional differences in the incidence of the flea beetles were great and depended solely on the availability of host plants. Therefore it was difficult to establish any countrywide differences in the incidence of the beetles.

Only Phyllotreta undulata (Kutsch.) and $P$. striolata $(\mathrm{F}$.) were of any importance as pests of rapeseed. $P$. undulata made up some $80-90 \%$ and $P$. striolata some $10 \%$ of the total number of flea beetles on rapeseed. $P$. striolata was more abundant on radish than on rapeseed. Sugarbeet was damaged only by Chaetocnema concinna (Marsh). Other species of flea beetles were also observed in small numbers on rapeseed, radish and sugarbeet. They did not, however, cause any damage, but spread from adjacent cultivated plant species or weeds. The suction trap collected only a few flea beetles, but clearly revealed their activity periods.

Damage caused by flea beetles is most harmful during the short seedling stage. At that time one flea beetle per plant was considered the threshold level for control measures. Later, even several flea beetles did not significantly hamper the growth. Seed coating efficiently prevented damage by flea beetles. The general incidence of flea beetles observed during this study was so low that coating of the seed was not justified. Chemical control of blossom beetle efficiently reduced flea beetles as well. The abandoning of the cultivation of winter rape also reduced the total number of flea beetles.
\end{abstract}

Index words: flea beetles, sugarbeet, rapeseed, control. 


\section{Introduction}

In Finland, 86 species of flea beetles (Coleoptera, Chrysomelidae, Halticinae) have been described (Silfyerberg 1979). Most of the species live on native plants, although there are some harmful species, especially among Phyllotreta and Chaetocnema. Phyllotreta lives almost exclusively on plants belonging to the family of Cruciferae but also on closely related Reseda-species and on Tropaeolum. Only Phyllotreta vittula (Redt.) lives on the family of Graminae (Heikertinger 1912, 1954, FreUde et al. 1966). Chaetocnema lives primarily on plant species of Polygonaceae, Chenopodiaceae, Cyperaceae, Juncaceae and Graminae (Heikertinger 1954). Of the nine Chaetocnema species found in Finland, four are considered to be pests, Chaetocnema concinna being the most harmful (VAPPULA 1962).

The significance of flea beetles as permanent pests has been known for decades. The worst damage occurs early in the spring on cultivated Cruciferae and sugarbeet, when overwintered adults devour cotyledons. Tullgren (1929), Rostrup (1940), MüHlow and Sylven (1953), VAppula (1962) and NielSEN (1977) and others have studied the distribution and biology of flea beetles in the Nordic countries. In general their global distribution and biology are rather well known (e.g. Heikertinger 1912, 1954, Blunck 1921, LÖTtge 1955, Burgess 1977 and SOMMER 1981). In Finland, the distribution of flea beetles and their host plants have been studied by Poppius (1901), LinNaniemi (1916, 1920 a, 1920 b, 1935), SaAlas (1933) and Vappula (1962). In spite of their annual occurrence and regular control, the quantitative relationships of flea beetle species and threshold levels have not yet been studied at any level. On the other hand, studies on the control methods have been numerous (e.g. JAMESON 1958, TIITTANEN \& VARIS 1960, 1961, 1963, Kinoshita et al. 1978, LAMB 1984).

The aim of this study is to explore the quantitative relationships in the flea beetle fauna, their fluctuation within the growing season and from year to year as well as the damage caused by flea beetles, and the threshold levels for control measures. The ability of flea beetles to move to their host plants and other factors of orientation were also observed.

\section{Material and methods}

Over 60000 flea beetles were collected using different trapping methods in 1972 and 198083. Most of the experiments were carried out at the Agricultural Research Centre in Vantaa. In 1983, flea beetles were also collected at eight localities in southern Finland. The species identification is based on the following works: Heikertinger (1912), SaAlas (1933), Freude et al. (1966) and Keilbach (1966). Weather data are from the Kaisaniemi weather station in Helsinki.

\subsection{Emergence of overwintered flea beetles and abundance and species composition on rapeseed, radish and sugarbeet}

Flea beetles were collected with Hardee ${ }^{\odot}$ yellow bollweevil traps (Pest Management Specialists) and yellow and transparent pitfall traps. The traps were emptied daily or two to three times a week. The diameter of the pitfall trap was $18 \mathrm{~cm}$. The sweepnet was used later in the growing season. The net diameter was $30 \mathrm{~cm}$ and one sample consisted of 100 single sweeps.

\subsection{Orientation of flea beetles}

Orientation of flea beetles to host plants was studied by placing greenhouse-reared young radish plants in 40 by $60 \mathrm{~cm}$ boxes out in the field at various distances from known overwintering sites in the beginning of the growing season. The boxes were placed in 12 sites, half of them on ploughed field and the other half on grass. Two boxes were placed five metres apart in each location, one with a transparent plastic cover. Flea beetles were 
trapped on a 20 by $20 \mathrm{~cm}$ glued transparent plate placed adjacent to each box and checked three times a week. The aim was to find out the role of odour and distance in the orientation of flea beetles in the spring.

\subsection{Use of suction trap}

A Johnson-Taylor suction trap (JoHNSON 1950) $1.2 \mathrm{~m}$ above ground level was used in 1981-82. In 1981 the trap was used from 9 May to 5 August and in 1982 from 11 May to 7 September. The number of flea beetles caught each day was recorded and the beetles identified by species.

\subsection{Regional differences in flea beetle fauna and its abundance}

Flea beetles were collected with transparent pitfall traps at eight localities in South and Central Finland. At each locality five traps were placed in a rapeseed field of at least half a hectare in size. Flea beetles were caught for about one month in the beginning of the growing season.

\subsection{Damage caused by flea beetles and threshold level for control measures}

The effect of flea beetles on the seed yield of rapeseed was studied in 1980 using cylinder experiments. Four 10 by $10 \mathrm{~m}$ plots were sown on 16 May. The variety was "Torch» (untreated). Thirteen cylinders, each enclosing ten young rapeseed plants, were placed in each plot. Flea beetles collected from fields with the bollweevil traps were placed inside the cylinders in various numbers and intervals. From 2 to 9 June, 4 cylinders in each study plot contained 1, 2 and 3 flea beetles/plant and the control, and from 2 to 17 June, 2 to 21 June and 9 to 21 June respectively 1 and 2 flea beetles/plant and the control. Rapeseed was at the seedling stage on June 2 and by June 9 young plants already had first pair of true leaves. After that the flea beetles and the cylinders were removed. The plants of the cylinder ex- periment were manually threshed when mature and seed yield determined.

In 1982, twelve cages measuring 50 by 50 by $180 \mathrm{~cm}$ with metal frames and cheesecloth covering were laid in the field on June 4. Inside each cage there were 90 rapeseed seedlings. Flea beetles were collected from fields and released inside the cages as follows: 100 in each of four cages, 50 in each of another four cages, and four cages formed a control group. Flea beetles were kept in these cages until June 13, when 20 seedlings from each cage were sampled and feeding signs counted.

In 1981, in Vantaa, the rapeseed variety "Torch" was grown in two densities, $2.2 \mathrm{~kg}$ of seed/ha and $8 \mathrm{~kg}$ of seed/ha. Sowing day was May 18 and on June 8 ten plants were sampled from each of four replicates and the feeding signs counted. The plant density was counted on June 10 (based on $2 \mathrm{x}$ no. of plants $/ 50 \mathrm{~cm}$ ). Before harvesting, 20 plants from each replicate were collected. The length, diameter and the number of siliques on the main stem, the number of racemes and the number of siliques on them were measured.

\subsection{Control experiments}

Control experiments were carried out in Vantaa in 1981-82 and in Jokioinen in 1983. In 1981, the experiment was established on May 18. The rapeseed variety was "Torch" and the fertilization level $100 \mathrm{~kg} \mathrm{~N} / \mathrm{ha}$. The harvested plot size was $12.0 \mathrm{~m}^{2}$. The treatments were:

E - untreated, $8 \mathrm{~kg}$ of seed/ha

$\mathrm{F}$ - treated with isofenphos $(30 \mathrm{~g} / \mathrm{kg}$ of seed),

$8 \mathrm{~kg}$ of seed/ha

$\mathrm{G}$ - untreated, $4.5 \mathrm{~kg}$ of seed/ha

$\mathrm{H}$ - untreated, $2.2 \mathrm{~kg}$ of seed/ha

$\mathrm{J}$ - pelletized seed, $8 \mathrm{~kg}$ of seed/ha.

The feeding signs were sampled and counted on June 8 .

In 1982, the experiment was established on May 13-14, in the abovementioned way. The treatments were:

A - untreated, $12 \mathrm{~kg}$ of seed/ha 
B - treated with isofenphos $(30 \mathrm{~g} / \mathrm{kg}$ of seed $)$ (treatment a), $12 \mathrm{~kg}$ of seed/ha

$\mathrm{C}$ - treated with hydroxyisoxazole $(15 \mathrm{~g} / \mathrm{kg}$ of seed), benomyl ( $2 \mathrm{~g} / \mathrm{kg}$ of seed) and carboxin $(0,5 \mathrm{~g} / \mathrm{kg}$ of seed) (treatment b), $12 \mathrm{~kg}$ of seed/ha

$\mathrm{G}$ - treatment b, $16 \mathrm{~kg}$ of seed/ha

$\mathrm{H}$ - untreated, $6 \mathrm{~kg}$ of seed/ha.

The plant density was counted on June 3 and on June 820 plants from each replicate were sampled and feeding signs counted.

The control experiment in Jokioinen was sown on 23 May 1983. The variety was "Sigga" fertilized with $100 \mathrm{~kg} \mathrm{~N} / \mathrm{ha}$. The treatments were as in 1982 . The plant density was recorded on June 6 . Two weeks after the emergence, 20 plants from each replicate were sampled and flea beetle feeding signs were counted.

In 1982, screening test for new prospective coating substances was conducted in Vantaa. The rapeseed variety was "Span" sown on May 24. There were seven coatings each with four replicates:

A - the untreated control

B - treated with isofenphos $(40 \mathrm{~g} / \mathrm{kg}$ of seed)

$\mathrm{C}$ - treated with isofenphos $(20 \mathrm{~g} / \mathrm{kg}$ of seed $)$

D - treated with captan $(30 \mathrm{~g} / \mathrm{kg}$ of seed)

E - treated with Kemira (experimental) no.

$2(30 \mathrm{~g} / \mathrm{kg}$ of seed)

F - treated with Kemira (experimental) no. $5(30 \mathrm{~g} / \mathrm{kg}$ of seed)

$\mathrm{G}$ - treated with lindane ( $50 \mathrm{~g} / \mathrm{kg}$ of seed)

On June 2, flea beetle feeding signs were counted. The plant density was recorded on June 21.

Flea beetles were also found in blossom beetle control experiments. These experiments were carried out in 1980 and in 1981 in Vantaa. The variety was "Torch" fertilized with $100 \mathrm{~kg} \mathrm{~N} / \mathrm{ha}$. The treated plots were sprayed twice with permethrin before flowering. In 1980 , netting of beetles began on June 13 . Samples consisting of 60 single sweeps were taken from both treated and untreated plots three times a week until August 18. In 1981, netting began on June 18 and samples were taken three times a week until August 6. Flea beetles were separated from the material, identified by species and counted.

\section{Results}

\subsection{Emergence of flea beetles from overwintering}

In 1982, the first overwintered flea beetles were observed as early as April 25. In the following year the first observations were two weeks later, on May 9. Thus the time of emergence varied considerably. This was primarily due to the early spring weather, but apparently also to the location of the overwintering site. The majority of flea beetles, however, emerged during the second half of May, when both day and night temperatures became markedly higher (Fig. I).

\subsection{Orientation of flea beetles to host plants}

The orientation of flea beetles to host plants was observed by using young radish plants. These were placed out in the field well before the emergence of flea beetles and before the appearance of any green vegetation. The results indicate that flea beetles were attracted by the odour of radish plants even to the bare, ploughed field (Fig. 2). Visual orientation

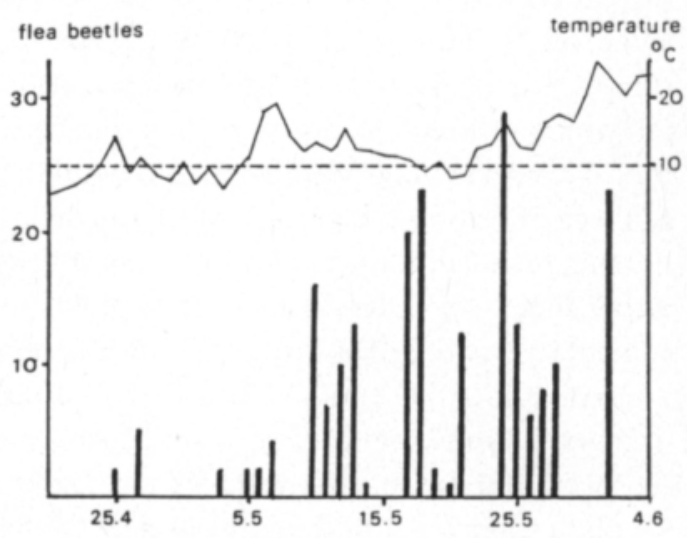

Fig. 1. Numbers of flea beetles caught with 10 yellow pitfall traps placed on grass from 24 April to 1 June 1982 and maximum daily temperatures in Vantaa. 

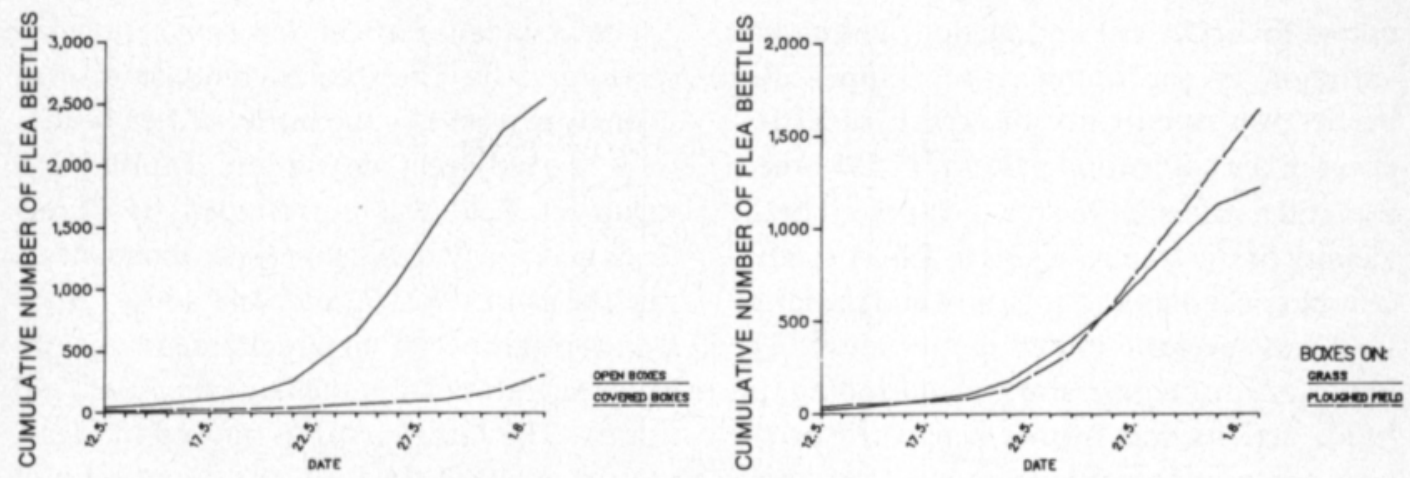

Fig. 2. Numbers of flea beetles caught on radish boxes from 10 May to 2 June 1982 in Vantaa.

seemed to be of little importance, for clearly visible but covered radish plants attracted few flea beetles. Flea beetles became active when daytime temperatures exceeded $+15^{\circ} \mathrm{C}$ while extended movement occurred at temperatures above $+20^{\circ} \mathrm{C}$. These experiments also indicated that flea beetles move rather short distances i.e. only a few hundred metres. When the food supply is near, the movement is reduced to less than a hundred metres. This is supported by the observation that, in the autumn, flea beetles remained on host plants until late retirement to overwintering sites in October, while some even overwintered in winter turnip rape fields. Radish plants attracted especially Phyllotreta undulata and $P$. striolata, which live on Cruciferae-species, but other species were represented by only a few randomly caught specimens.

\subsection{Suction trap observations}

Compared with other collecting methods, the suction trap observations (Fig. 3) quite clearly indicated the appearance and activity period of flea beetles during the growing season. On the other hand, the rather low numbers indicated that flea beetles move close to the ground and only short distances. They did not even reach the one metre height re-

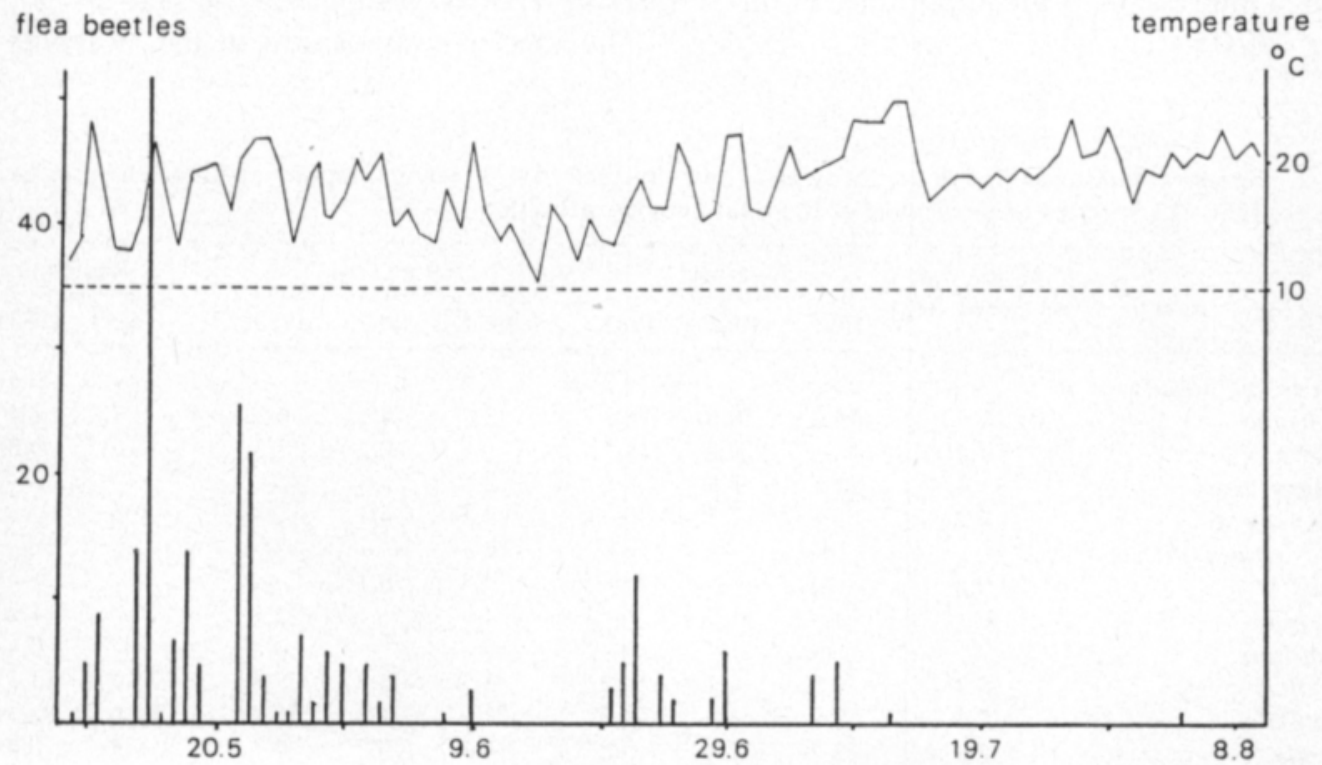

Fig. 3. Daily yields of suction trap and the maximum temperatures in Vantaa from 9 May to 8 August 1981 . 
quired for effective trap function. The annual variation in the numbers of trapped flea beetles was apparently the result of differences in the cultivation pattern. In 1981 there was still a rather large area of rapeseed in the vicinity of the trap, whereas in 1982 the adjacent plot was only about 10 ares and the larger field was several hundred metres away. The importance of temperature in controlling flea beetle activity was further supported by the trap observations. Numbers were abundant only when the daytime temperature exceeded $+20^{\circ} \mathrm{C}$. In 1982 , there was a ten day cold period in May. The daytime temperature was only about $+12^{\circ} \mathrm{C}$ and no flea beetles were found in the suction trap.

\subsection{Species composition}

In spring, before the growing season, traps placed on grass and ploughed field collected several species of flea beetles (Table 1.). At this time flea beetles were moving in the vicinity of overwintering sites searching for suitable host plants.

The species found on young sugarbeet plants in 1981-83 are shown in Table 1. The numbers of flea beetles were always very low, and the percentage distribution thus gives a distorted impression of the importance of different species.
The abundance of Chaetocnema concinna varied greatly. The species composition was strongly affected by the influx of flea beetles from the adjacent vegetation. In 1981 the sugarbeet field was surrounded by barley fields and Phyllotreta vittula was abundant on sugarbeet. In 1982, P. undulata and P. striolata, typical species on Cruciferae plants, invaded sugarbeet from the large rapeseed field nearby. The Longitarsus sp. moved to sugarbeet from weeds. In 1983, the sugarbeet plot of 1 are was surrounded by rapeseed and radish plots of the same size and the proportion of Chaetocnema concinna remained small.

Phyllotreta undulata was the dominant species on young rapeseed plants (Table 1 ). Its proportion varied from $75 \%$ to $85 \%$. In 1981 , the rapeseed plot was in the middle of a barley field, which explains the proportion of $P$. vittula. The abundance of $P$. striolata varied from $3 \%$ to almost $9 \%$. Of other species only a few specimens were found and they were thus insignificant as pests.

Young radish plants attracted flea beetles quite effectively (Table I). The species composition and relative abundance were of similar type as described for rapeseed. However, the proportion of $P$. striolata was greater than on rapeseed, being from $14 \%$ to $24 \%$.

The species composition in the sweepnet

Table 1. Species composition of flea beetles on grass and ploughed field, sugarbeet, rapeseed and radish in spring $1981-83$ in terms of percentage of the total number of beetles.

\begin{tabular}{|c|c|c|c|c|c|c|c|c|c|}
\hline & \multirow{2}{*}{$\begin{array}{c}\text { Grass and } \\
\text { ploughed field }\end{array}$} & \multicolumn{3}{|c|}{ Sugarbeet } & \multicolumn{3}{|c|}{ Rapeseed } & \multicolumn{2}{|c|}{ Radish } \\
\hline & & 1981 & 1982 & 1983 & 1981 & 1982 & 1983 & 1982 & 1983 \\
\hline Chaetocnema aridula & - & - & - & 4.8 & - & - & - & - & 0.4 \\
\hline C. concinna & 18.9 & 76.3 & 28.6 & 11.3 & 2.7 & 4.0 & 0.2 & 0.7 & 1.4 \\
\hline C. hortensis & 3.5 & - & 0.8 & 15.3 & - & 0.5 & 3.3 & 0.3 & 0.8 \\
\hline C. mannerheimi & 11.4 & 1.8 & 2.8 & 1.6 & 2.5 & - & - & - & - \\
\hline Longitarsus sp. & 7.2 & 1.8 & 12.5 & - & 2.5 & 4.1 & - & 0.5 & - \\
\hline Phyllotreta armoraciae & - & - & - & - & 0.5 & - & - & - & - \\
\hline P. atra & 0.2 & - & - & - & 0.3 & 0.1 & - & - & - \\
\hline P. flexuosa & - & - & - & - & - & - & 2.1 & - & 1.2 \\
\hline P. nemorum & - & - & - & - & - & - & 0.2 & - & 0.4 \\
\hline P. striolata & 3.4 & 0.9 & 8.1 & 23.4 & 3.3 & 6.3 & 8.8 & 24.4 & 13.5 \\
\hline P. undulata & 22.3 & 7.0 & 44.8 & 42.7 & 73.9 & 84.3 & 85.1 & 73.6 & 82.1 \\
\hline P. vittula & 32.9 & 12.3 & 2.4 & 0.8 & 14.3 & 0.3 & 0.2 & 0.5 & 0.4 \\
\hline Total no. flea beetles & 2591 & 114 & 248 & 124 & 384 & 800 & 422 & 2529 & 513 \\
\hline
\end{tabular}


Table 2. Species composition of flea beetles in sweepnet samples collected in Isokyrö in 1972 and in Vantaa in $1980-83$ in terms of percentage of the total number of beetles.

\begin{tabular}{|c|c|c|c|c|c|c|c|c|}
\hline & \multirow{2}{*}{\multicolumn{2}{|c|}{ Isokyrö 1972}} & \multicolumn{6}{|c|}{ Vantaa } \\
\hline & & & \multicolumn{4}{|c|}{ Rapeseed } & \multirow{2}{*}{$\begin{array}{c}\text { Radish } \\
1983\end{array}$} & \multirow{2}{*}{$\begin{array}{c}\text { Sugarbeet } \\
1983\end{array}$} \\
\hline & $\begin{array}{l}\text { Swede } \\
\text { rape }\end{array}$ & $\begin{array}{c}\text { Turnip } \\
\text { rape }\end{array}$ & 1980 & 1981 & 1982 & 1983 & & \\
\hline Chaetocnema aridula & - & - & - & - & - & - & - & - \\
\hline C. concinna & - & 0.7 & 1.9 & 0.3 & 0.3 & 0.4 & 0.5 & 30.5 \\
\hline C. hortensis & - & - & - & - & - & 0.1 & - & - \\
\hline C. mannerheimi & - & - & - & - & - & - & - & - \\
\hline Longitarsus sp. & - & - & - & - & - & 0.5 & - & 2.0 \\
\hline Phyllotreta armoraciae & - & - & - & - & - & - & - & - \\
\hline P. atra & 0.2 & - & - & - & - & - & - & - \\
\hline P. flexuosa & - & - & - & - & - & - & - & - \\
\hline P. nemorum & - & - & - & - & - & - & 1.3 & - \\
\hline P. striolata & 26.1 & 43.4 & 6.4 & 1.6 & 6.5 & 33.8 & 63.2 & 63.0 \\
\hline$P$. undulata & 73.7 & 55.9 & 89.1 & 97.2 & 92.7 & 65.0 & 34.4 & 4.5 \\
\hline P. vittula & - & - & 2.7 & 0.9 & 0.3 & 0.1 & 0.4 & - \\
\hline Total no. flea beetles & 1704 & 4952 & 36558 & 958 & 789 & 786 & 2305 & 246 \\
\hline
\end{tabular}

samples is presented in Table 2. The samples from Isokyrö are interesting because rapeseed and sugarbeet had not been cultivated in the region for ten years before the sampling. Thus the species composition to a great extent represents the natural flea beetle fauna of the region.

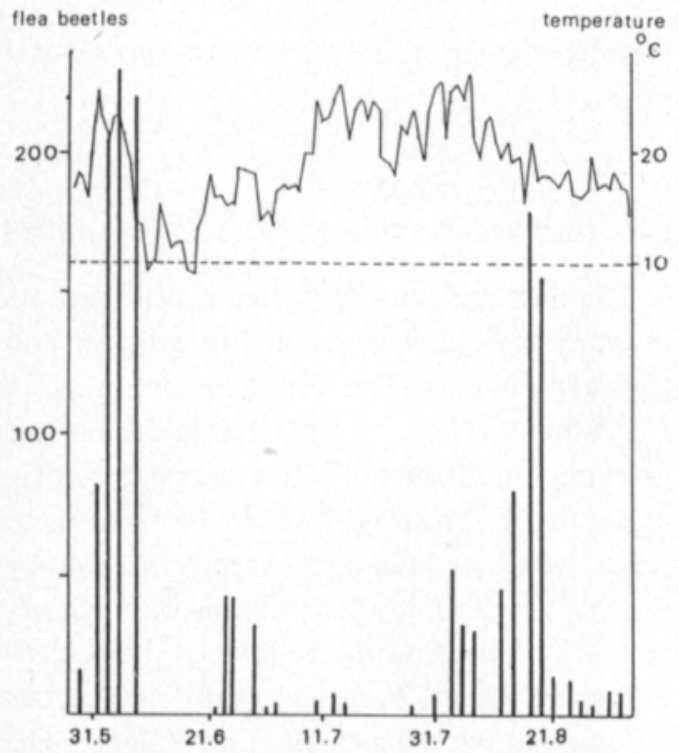

Fig. 4. Numbers of flea beetles collected on rapeseed with 18 transparent pitfall traps (27. 5.-7. 6.) and sweepnet (21. 6.-1.9.) and the maximum daily temperatures in 1982 in Vantaa.
The results of the $1981-82$ netting from rapeseed indicate that the proportion of $P$. undulata in the new generation continued to increase. Table 2 shows how $P$. striolata favoured radish. It also dispersed to rapeseed and sugarbeet, whereas Chaetocnema concinna moved to neither rapeseed nor radish.

\subsection{Abundance of flea beetles}

During the growing season two peaks of abundance occurred (Fig. 4). The first peak in May-June consisted of overwintered flea beetles and the other in July-August of adults of the new generation. The incidence of flea beetles varied greatly also from year to year. The incidence of flea beetles on the experiment area in Vantaa seemed to decrease with a decrease in the cultivation area of rapeseed and sugarbeet. In 1979-80, there was still a 0.5 hectare plot of winter turnip rape on which flea beetles thrived. Later in summer great numbers of flea beetles of the new generation moved to spring turnip rape nearby. In 198081 , spring turnip rape was treated against blossom beetles and that reduced also flea beetle numbers effectively (Table 3 ). 
Table 3. Numbers of flea beetles in sweepnet samples collected from the blossom beetle control experiments in 1980 (two fields, I and II) and 1981 (field I).

\begin{tabular}{lccc}
\hline & 1980, I & 1980, II & 1981, I \\
& $13.6 .-18.8$ & $13.6 .-18.8$ & $18.6 .-6.8$. \\
\hline Treated plot (A) & 20210 & 236 & 431 \\
Control plot (B) & 36558 & 377 & 958 \\
A:B (\%) & 55.3 & 62.6 & 45.0 \\
\hline
\end{tabular}

Table 4. Species composition of flea beetles collected with five transparent pitfall traps on rapeseed at seven experimental stations in terms of percentage of the total number of beetles.

\begin{tabular}{|c|c|c|c|c|c|c|c|}
\hline & $\begin{array}{l}\text { Agric. Res. } \\
\text { Centre } \\
\text { Jokioinen }\end{array}$ & $\begin{array}{l}\text { Satakunta } \\
\text { exp. sta. }\end{array}$ & $\begin{array}{l}\text { South-west } \\
\text { exp. sta. }\end{array}$ & $\begin{array}{l}\text { Central } \\
\text { Finland } \\
\text { exp. sta. }\end{array}$ & $\begin{array}{l}\text { South Savo } \\
\text { exp. sta. }\end{array}$ & $\begin{array}{l}\text { Kymenlaakso } \\
\text { exp. sta. }\end{array}$ & $\begin{array}{l}\text { Porvoo } \\
\text { commune }\end{array}$ \\
\hline Chaetocnema & - & - & - & - & - & - & - \\
\hline C. concinna & 3.9 & 2.9 & 13.3 & - & 9.2 & 1.1 & 25.3 \\
\hline C. hortensis & 0.8 & - & - & - & 5.9 & - & 5.6 \\
\hline C. mannerheimi & - & 0.7 & 23.3 & 1.2 & - & - & 4.0 \\
\hline $\begin{array}{l}\text { Longitarsus sp. } \\
\text { Phyllotreta }\end{array}$ & - & 0.7 & - & 1.2 & 0.8 & 6.7 & 5.6 \\
\hline armoraciae & - & - & - & - & - & - & - \\
\hline P. atra & - & - & - & - & - & - & - \\
\hline P. flexuosa & 0.1 & - & - & - & - & - & - \\
\hline P. nemorum & - & - & - & - & - & - & 0.5 \\
\hline P. striolata & 17.9 & 8.0 & - & 17.7 & 12.6 & 1.1 & 3.5 \\
\hline P. undulata & 71.7 & 87.7 & 50.0 & 80.0 & 71.4 & 91.1 & 54.0 \\
\hline $\begin{array}{l}\text { P. vittula } \\
\text { Total no. flea }\end{array}$ & 5.4 & - & 13.3 & - & - & - & 1.5 \\
\hline beetles & 736 & 260 & 119 & 260 & 119 & 90 & 198 \\
\hline
\end{tabular}

\subsection{Regional species composition and abundance of flea beetles}

The species composition of flea beetles collected at various experimental stations is presented in Table 4. Phyllotreta undulata was the dominant species in all regions, its relative abundance varying from $50 \%$ (SW-Finland Exp.Sta.) to $91 \%$ (Kymenlaakso Exp. Sta.). P. striolata was the second most common species and its proportion seemed to increase northwards. In Porvoo commune, sugarbeet was grown near the rapeseed field, which explains the abundance of Chaetocnema concinna. Conclusions about the regional abundance cannot be made from these results because flea beetles are rather local in occurrence. For example, the numbers of flea beetles were low at the Southwest Finland Exp. Station although Cruciferae plant spe- cies have been cultivated there for several years.

\subsection{Damage and threshold levels for control}

The damage caused by flea beetles and its impact on yield were studied in cylinder and cage experiments. The results are presented in Fig. 5 and Table 5. It seems that in the average growing conditions one flea beetle per cotyledon is the threshold level for control measures. However, damage is greatly affected by the growing conditions. Serious damage occurred only during the relatively short seedling stage. Later, even numerous flea beetles did not hamper the growth of host plants. The rather high plant density, 350 plants $/ \mathrm{m}^{2}$, is a good protection against damage, for in the usual growing conditions the threshold level of 
Table 5. Effect of flea beetles on the seed yield of rapeseed in the cylinder experiments in 1980 in Vantaa.

\begin{tabular}{lcccc}
\hline Period & Control & \multicolumn{3}{c}{ Seed yield, g/10 plants } \\
\cline { 3 - 5 } & & 1 beetle/plant & 2 beetles/plant & 3 beetles/plant \\
\hline 2. 6.-9.6. & $7.90 \pm 2.59$ & $3.43 \pm 1.24$ & $2.51 \pm 1.53$ & $1.65 \pm 0.49$ \\
2. 6.-17.6. & $5.90 \pm 1.59$ & $2.48 \pm 0.59$ & $1.40 \pm 1.16$ & $\ldots$ \\
$9.6 .-21.6$. & $6.43 \pm 1.40$ & $8.24 \pm 2.62$ & $7.27 \pm 2.86$ & $\ldots$ \\
\hline
\end{tabular}

one flea beetle per cotyledon is very seldom reached. On the other hand, rapeseed is capable of efficiently compensating for early thinning of the plant stand (Table 6).

\subsection{Control measures}

For decades flea beetles have been controlled by routinely coating the seed. In the experiment carried out in 1980-83 it was found that the products used protected the cotyledons as expected (Tables 7 to 9). Of the new products, captan was found to be as effective as isofenphos, which was rather effective also in low dosage. When the results of 1982 and 1983 are compared, the effects of the growing conditions upon the emergence and the compensation capability of rapeseed and the amount of damage are all clearly observable. In the average growing conditions of 1982 the effect of the coating was positive, but its significance decreased in 1983 when the

\section{holes/plant}

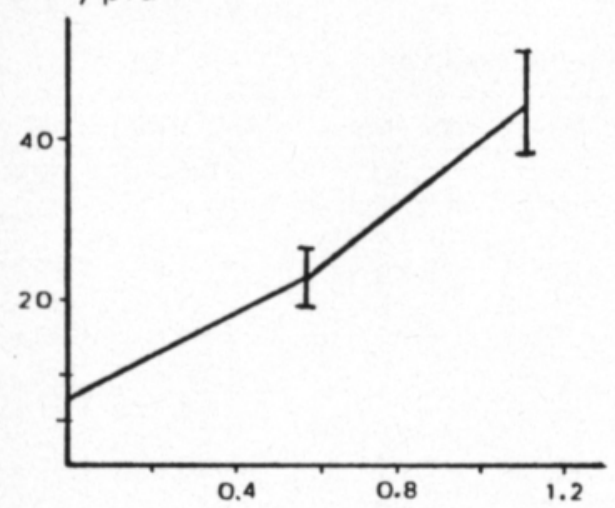

flea beetles/ plant

Fig. 5. The feeding signs/plant in cages containing various numbers of flea beetles in the cage experiment in 1982 in Vantaa. growing conditions were better. During control experiments flea beetles did not occur in numbers that would require routine coating of the seed. On the other hand, as Table 3 shows, the control of blossom beetles in about mid-June reduced the numbers of flea beetles too.

Table 6. Comparison of the sparse seedling $(2.2 \mathrm{~kg} / \mathrm{ha})$ and the dense seedling $(8 \mathrm{~kg} / \mathrm{ha})$ of rapeseed in Vantaa in 1981.

\begin{tabular}{lrc}
\hline & $\begin{array}{c}\text { Sparse seedling } \\
(\overline{\mathrm{x}} \pm \mathrm{s})\end{array}$ & $\begin{array}{c}\text { Dense seedling } \\
(\overline{\mathrm{x}} \pm \mathrm{s})\end{array}$ \\
\hline $\begin{array}{l}\text { Plants } / 50 \mathrm{~cm} \\
\text { Feeding signs/plant }\end{array}$ & $7.5 \pm 0.6$ & $17.6 \pm 3.8$ \\
The main stem & $12.5 \pm 2.7$ & $12.3 \pm 4.4$ \\
$\quad \begin{array}{l}\text { Length }(\mathrm{cm}) \\
\text { Siliques }\end{array}$ & $99.3 \pm 5.6$ & $99.5 \pm 8.0$ \\
$\quad \begin{array}{l}\text { Diameter of the } \\
\text { main stem (mm) }\end{array}$ & $13.4 \pm 3.4$ & $21.5 \pm 6.9$ \\
Racemes & $6.6 \pm 1.1$ & $5.6 \pm 0.8$ \\
$\quad \begin{array}{l}\text { Siliques on the } \\
\text { racemes }\end{array}$ & $3.5 \pm 0.4$ & $2.8 \pm 0.4$ \\
The yield $(\mathrm{kg} / \mathrm{ha})$ & $1076.3 \pm 33.7$ & $1200.0 \pm 28.3$ \\
\hline
\end{tabular}

Table 7. Flea beetle feeding signs on rapeseed coated with various substances in Vantaa 1982.

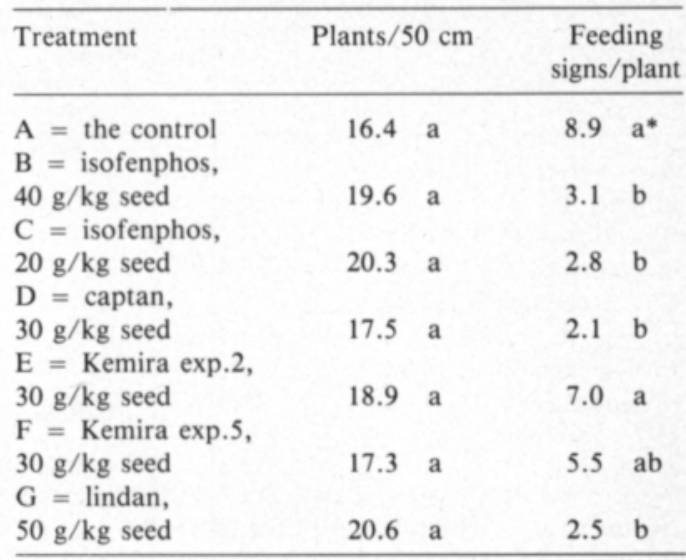

* Tukey's t-test 


\section{Discussion}

Flea beetles become active and emerge from overwintering sites when temperatures rise in spring. In southern Finland a few flea beetles can be found at the end of April, but most of them appear during the last third of May when night and daytime temperatures usually rise significantly. The emergence is affected by the temperature close to the ground. On sunny spring days this is often higher than the temperature two metres above the ground. Flea beetles also emerge earlier from sunny sites than from shaded ones (LÖTTGE 1955). No clear differences in the timing of emergence were observed between the species. Information in the literature is conflicting (e.g. Mưhlow \& Sylven 1953, LötTge 1955, Jones
\& Jones 1974), but Sommer (1981) too states that there are no clearly observable differences in the emergence of different species.

The lowest temperature in which BuRgess (1977) observed flying flea beetles was $+14-15^{\circ} \mathrm{C}$. According to BLunCK (1921) and LötTge (1955) the temperature must be at least $+18^{\circ} \mathrm{C}$ before flea beetles fly from overwintering sites to host plants. According to JoNEs \& Jones (1974) this dispersal flight does not begin before the daytime temperature reaches $+20^{\circ} \mathrm{C}$. The suction trap observations and the radish box experiments indicate that flea beetles fly longer distances only after the daytime temperature reaches about $+20^{\circ} \mathrm{C}$. However, flea beetles did also fly at lower temperatures than the $+18^{\circ} \mathrm{C}$ men-

Table 8. The flea beetle control experiment in Vantaa 1981.

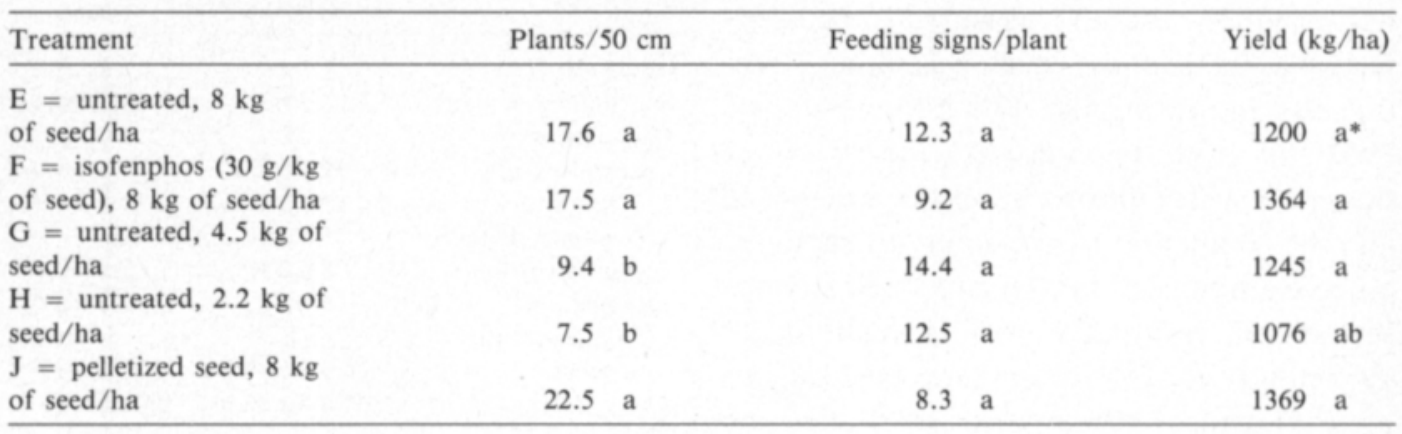

* Tukey's t-test

Table 9. Flea beetle control experiments in Vantaa 1982 and in Jokioinen 1983.

\begin{tabular}{|c|c|c|c|c|c|c|}
\hline \multirow[t]{2}{*}{ Treatment } & \multicolumn{2}{|c|}{ Plants $/ 50 \mathrm{~cm}$} & \multicolumn{2}{|c|}{ Feeding signs/plant } & \multicolumn{2}{|c|}{ Yield (kg/ha) } \\
\hline & 1982 & 1983 & 1982 & 1983 & 1982 & 1983 \\
\hline $\begin{array}{l}A=\text { untreated, } 12 \mathrm{~kg} \\
\text { of seed } / \text { ha } \\
B=\text { treatment a, } 12 \mathrm{~kg}\end{array}$ & 20.1 a & 20.6 a & $12.3 \mathrm{a}$ & 3.9 a & 1613 a & $1915 \mathrm{a}^{*}$ \\
\hline $\begin{array}{l}\text { of seed/ha } \\
C=\text { treatment } b, 12 \mathrm{~kg}\end{array}$ & $24.7 \mathrm{~b}$ & $26.3 \mathrm{a}$ & $9.2 \mathrm{a}$ & $1.9 \mathrm{~b}$ & $1650 \mathrm{a}$ & 1932 a \\
\hline $\begin{array}{l}\text { of seed } / \text { ha } \\
G=\text { treatment } b, 16 \mathrm{~kg}\end{array}$ & $19.3 \mathrm{a}$ & $18.5 \mathrm{ab}$ & $12.0 \mathrm{a}$ & $2.5 \mathrm{ab}$ & 1674 a & 1950 a \\
\hline $\begin{array}{l}\text { of seed/ha } \\
\mathrm{H}=\text { untreated, } 6 \mathrm{~kg}\end{array}$ & $25.9 \mathrm{~b}$ & 26.8 a & $12.8 \mathrm{a}$ & $2.3 \mathrm{~b}$ & 1686 a & 1951 a \\
\hline of seed/ha & $14.4 \mathrm{c}$ & $10.3 \mathrm{c}$ & $15.1 \mathrm{a}$ & $4.7 \mathrm{a}$ & 1422 a & 2056 a \\
\hline
\end{tabular}

treatment $\mathrm{a}=$ isofenphos $(30 \mathrm{~g} / \mathrm{kg}$ of seed $)$

treatment $\mathrm{b}=$ hydroxyisoxazole $(15 \mathrm{~g} / \mathrm{kg}$ of seed), benomyl $(2 \mathrm{~g} / \mathrm{kg}$ of seed), and carboxin $(0.5 \mathrm{~g} / \mathrm{kg}$ of seed)

* Turkey's t-test 
tioned by BLunCK (1921) and LötTGE (1955). For instance, the lowest daytime temperature at which the suction trap caught flea beetles was $+13.5^{\circ} \mathrm{C}$. The trap catches insects at a height of 1-2 $\mathrm{m}$ in the air (JoHnson 1950), and the flea beetles caught were thus apparently on an extended flight. The suction trap observations quite clearly indicate the timing of emergence and the mobility of flea beetles during the growing season.

According to SOMMER (1981) the availability of host plants in spring greatly affects the development of flea beetle populations. This was also clearly observed in summer 1980 in Vantaa. The winter turnip rape field provided an ample food supply for flea beetles in spring. They reproduced extremely well, and the new generation moved in masses to feed on the adjacent spring rape field. The cultivation of winter turnip rape ceased in Finland in the mid 1970s, which to some extent at least has evidently kept flea beetle populations rather low recently.

According to Moreton (1945) flea beetles disperse randomly during favourable weather conditions and are not attracted by Cruciferaespecies. Numerous other studies indicate, however, that flea beetles find their Cruciferae host plants by olfactory orientation. Mustard oils and mustard oil glucosides function as attractants (Görnitz 1953, 1956, FeEny et al. 1970, HiCKS 1974, NiELSEN 1977). In addition, initiation of feeding is affected by feeding inhibitors these plants contain, such as glucosinolates and flavonoids (NIELSEN et al. 1977, Nielsen 1978, Vargas \& Kershaw 1979). The radish box experiments also clearly indicated that flea beetles are attracted to their host plants by odour cues. Radish attracted only Phyllotreta undulata and $P$. striolata, which feed on Cruciferae species. Of other species, only a few beetles were caught, as also on the covered radish boxes.

The flea beetle species on cultivated plants in Finland have been studied by a few authors, such as LinNANiEmi (1920 b, 1935), SAALAS (1933) and Vappula (1962). According to VAPPULA (1962), of the flea beetles found on
Cruciferae-species, Phyllotreta undulata is especially harmful, $P$. atra, $P$. nemorum (L.) and $P$. striolata being quite harmful. Chaetocnema concinna is especially harmful on beets. The experiments in 1972 and 1980-83 indicate, however, that only $P$. undulata and $P$. striolata had any significance as pests of Cruciferae-species. Chaetocnema concinna is the only flea beetle species damaging sugarbeet in Finland. During this study it was rather rare, but on extensive sugarbeet fields it may increse rapidly. Flea beetles normally living on other cultivated plant species or weeds moved also to rapeseed, radish and sugarbeet, but they did not cause damage.

No clear differences between the species composition were observed in southern and central Finland. $P$. undulata was the most common species, $P$. striolata being the second. The relative abundance of $P$. striolata increased somewhat towards the north. The surrounding vegetation greatly affected the species composition at all collection sites. It is not possible to estimate the regional incidences of flea beetles for the numbers may vary greatly even within a small area. Continuous cultivation of suitable host plants will increase the abundance of flea beetles.

In Southern Finland the spring peak incidence was reached in May-June while the new generation appeared in July-August depending on the weather. In Finland flea beetles have only one generation per year. In Central Europe the peaks are reached earlier than in Finland, and at least $P$. undulata has been observed to have a second generation (Löttge 1955, Jourdheuil 1960, SOMMER 1981). Flea beetle numbers also fluctuate annually, depending, for instance, on weather conditions in the growing season and the availability of host plants (SOMMER 1981). The incidence may vary considerably even within a small area and even the polyphagous Phyllotreta species prefer some host plants to others (Haddock 1945, Dobson 1956, Sommer 1981),

The cylinder experiments clearly indicated that the relatively short seedling stage (about 
one week after germination) is the most sensitive period to flea beetle damage. Later, even several flea beetles did not hamper the growth. This is mentioned by TAYLOR (1968) and LAmв (1984), too. According to LAmB (1984) damage was most significant during the first weeks after germination. During the first week the seedling mortality was high and the growth was slow during the first couple of weeks. The spring weather also affects the magnitude of damage (Löttge 1955, Sommer 1981). According to LeBedeV (1924) and PIMENTEL (1961) flea beetles are more numerous in sparse than in dense growth. In the present study the numbers of flea beetles per sq.metre were so low that no difference in damage was observed between the sparse and dense growths. The sowing density of rapeseed, 350 seedlings $/ \mathrm{m}^{2}$, provides a good protection against damage. Rapeseed is also able to compensate for the seedling loss by branching.

For decades seeds have been coated to prevent damage by flea beetles. These experiments indicated that the products now in general use reduce flea beetle damage effectively. Spraying against blossom beetles effectively reduced the numbers of flea beetles as well.

\section{Literature}

BLunck, H. 1921. Erdflohkäfer an den ölsaaten im Jahre 1920. Arbeiten aus der Biol. Reichsanstalt 10: 406-466. Berlin.

Burgess, L. 1977. Flea beetles (Coleoptera: Chrysomelidae) attacking rape crops in the Canadian provinces. Can. Ent. 109: 21-32.

Dobson, R.M. 1956. A note on the relative abundance of flea beetles (Phyllotreta Stephens and Psylliodes Berthold) on different cruciferous crops. J. Hort. Sci. 31: 291-294.

Feeny, P., Paauwe, K.L. \& Demong, N.J. 1970. Flea beetles and mustard oils: host plant specificity of Phyllotreta cruciferae and $P$. striolata adults (Coleoptera: Chrysomelidae). Ann. Ent. Soc. Am. 63: 832-841.

Freude, H., Harde, K.W. \& Lohse, G.A. 1966. Die Käfer Mitteleuropas. Part 9. Cerambycidae, Chrysomelidae. 299 p. Krefeld.

Gornitz, K. 1956. Untersuchungen über in Cruciferen enthaltene Insekten-Attraktivstoffe. Nachr.bl. dt. Pfl.schutzd. N.F. 7: 81-95.

HAdDock, M.J. 1945. Observations on the species of flea beetles infesting Brassica crops in the west of England. Ann. Rep. Long Ashton Res. Sta. for 1944: 166-169.

Heikertinger, F. 1912. Halticinae. Fauna Germanica: Die Käfer des Deutchen Reiches. Part IV. p. 143-212. Stuttgart.

- , 1954. Halticinae. Handbuch der Pflanzenkrankheiten. Part V. Berlin and Hamburg.

Hıcks, K.L. 1974. Mustard oil glucosides: feeding stimulants for adult cabbage flea beetles Phyllotreta cruciferae (Coleoptera, Chrysomelidae). Ann. Ent. Soc. Am. 67: $261-264$.

JAMESON, H.R. 1958. The mechanism of control of turnip flea beetle by benzene hexachloride dressings on brassica seeds. J. Sci. Food Agric. 9: 590.

Johnson, C.G. 1950. A suction trap for small airborne insects which automatically segregates the catch into successive hourly samples. Ann. Appl. Biol. 37: 80-91.

Jones, F.G. \& Jones, M.G. 1974. Pests of field crops. Second edition. 448 p. New York.

JourdHEUIL, P. 1960. Remarques sur le nombre de generations de quelques Phyllotreta (Col., Chrysomelidae). Bull. Soc. Ent. Fr. 65: 126-131.

KeIlbaCH, R. 1966. Die tierischen Schädlinge Mitteleuropas. 784 p. Jena.

Kinoshita, G.B., Svec, H.J. \& Mceven, F.L. 1978. Laboratory and field studies on the chemical control of the crucifer flea beetle, Phyllotreta cruciferae (Coleoptera, Chrysomelidae), on cruciferous crops in Ontario. Can. Ent. 110: 795-803.

LAMB, R.J. 1984. Effects of flea beetles, Phyllotreta spp. (Coleoptera, Chrysomelidae), on the survival, growth, seed yield and quality of canola, rape and yellow mustard. Can. Ent. 116: 269-280.

Lebedev, V.A. 1924. [On the means for combating garden insects of the genus Phyllotreta, and on the effect of these on the growth and yields of plants]. Zashch. Rast. 1: 131-138. In Russian, translation E. Matthews.

LINNANIEMI, W.M. 1916. 20. kertomus tuhohyönteisten esiintymisestä Suomessa vuonna 1914. Maanviljelyhall. Tied. III. 75 p.

—, 1920 a. Sokerijuurikasviljelyksen tuhohyönteiset ja niiden torjumiskeinot. 71 p. Helsinki.

-, 1920 b. $20-21(21-22)$ kertomus tuhoeläinten esiintymisestă Suomessa vuosina 1915 ja 1916. Maatal.hall. Tied. 131. $132 \mathrm{p}$.

-, 1935. 23. kertomus tuhoeläinten esiintymisestä Suomessa vuosina 1917-1923. Valt. Maatal. Koetoim. Julk. 68. 159 p. 
LOttge, W. 1955. Möglichkeiten einer Prognose bei Gemüseschädlingen erörtert am Beispiel der Kohlerdflöhe (Phyllotreta). Kühn-Arch. 69: 493-551.

Moreton, B.D. 1945. On the migration of flea beetles (Phyllotreta spp.) (Coleoptera, Chrysomelidae) attacking Brassica crops. Ent. Month. Mag. 81: 59-60. Ser. 4. London.

MÜlow, J. \& Sylven, E. 1953. Oljevăxternas skadedjur. Natur och Kultur. 163 p. Stockholm.

Nielsen, J.K. 1977. Host plant relationships of Phyllotreta nemorum L. (Coleoptera: Chrysomelidae). 1. Field studies. Z. Ang. Ent. 84: 396-407.

-, Larsen, L.M. \& Sorensen, H. 1977. Cucurbitacin E and $\mathrm{I}$ in Iberis amara: feeding inhibitors for Phyllotreta nemorum. Phytochemistry 16: 1519-1522.

Pimentel, D. 1961. The influence of plant spatial patterns on insect populations. Ann. Ent. Soc. Amer. 54: $61-69$.

PoppIus, B. 1901. Über die Entwickelung von Phyllotreta armoraciae Koch. Medd. Soc. Fauna et Flora Fenn. 27: 106-111.

Rostrup, S. 1940. Vort Landbrugs Skadedyr. 400 p. Copenhagen.

SAALAS, U. 1933. Viljelykasvien tuho- ja hyötyhyönteiset sekả muut selkărangattomat eläimet. 676 p. Porvoo.

Silfverberg, H. 1979. Enumeratio Coleopterum Fennoscandiae et Daniae. Helsingin hyönteisvaihtoyhdistys. Helsinki.

\section{SELOSTUS}

\section{Kirpat (Coleoptera, Chrysomelidae, Halticinae) rypsi- ja sokerijuurikasviljelyksillä}

\author{
Arja Augustin, ${ }^{1}$ Unto Tulisalo ${ }^{1}$ ja \\ Seppo Korpela ${ }^{2}$ \\ 1 Oljynpuristamo Oy, SF-00810 Helsinki, Finland \\ ${ }^{2}$ Agricultural Research Centre, SF-13600 Jokioinen, \\ Finland
}

Maatalouden tutkimuskeskuksessa Vantaalla sekă seitsemällä muulla paikkakunnalla Etelä- ja Keski-Suomessa selvitettiin vuosina 1972 ja $1980-83$ kirppojen esiinty. mistä rypsi- ja sokerijuurikasviljelyksillä. Etelä-Suomessa ensimmäiset kirpat lähtivät liikkeelle talvehtimispaikoistaan lämpötilan mukaan huhti- ja toukokuun vaihteessa. Suurin osa kirpoista ilmestyi kuitenkin toukokuun loppupuoliskolla, kun păivălămpötilat ajoittain kohosivat $20^{\circ} \mathrm{C}$ :seen. Kirpat suunnistivat ja löysivăt isãntăkasvinsa hajun perusteella. Kasvukauden aikana oli kaksi run-
Sommer, G. 1981. Biologie und Parasitenkomplex der Halticinen Gattung Phyllotreta. 317 p.

TAYLOR, W.E. 1968. The effects of leaf eating insects, especially Plutella maculipennis Curtis and Phaedon cochleriae F. on the growth and yield of some cruciferous plants. Ph. D. Thesis, University of London.

TittAanen, K. \& VARIS, A.-L. 1960. The treatment of seeds of swede, turnip and turnip rape in the control of flea beetles (Phyllotreta spp.) and cabbage root flies (Hylemyia brassicae Bouche and H. floralis Fall.). Valt. Maatalouskoetoim. Julk. 181: 1-11.

—, \& V VRIS, A.-L. 1961. Ristikukkaisten rehukasvien siementen lindaanikäsittely kaalikärpästen ja kirppujen torjunnassa. Maatal. ja Koetoim. 15: 264-274.

-, \& V ARIS, A.-L. 1963. The effect of storage on the germination of lindane treated seeds and on the efficacy of such treatment in controlling flea beetles ( $\mathrm{Phyl}$ lotreta spp.) and cabbage root flies (Hylemyia spp.). Ann. Agríc. Fenn 2: 44-50.

Tullgren, A. 1929. Kulturväxterna och djurvärlden. 387 p. Stockholm.

VAPPULA, N.A. 1962. Suomen viljelykasvien tuhoeläinlajisto. 275 p. Helsinki.

VARGas, P. \& Kershaw, W.J.S. 1979. Host selection and choice of feeding site by the flea beetle Phyllotreta undulata Kutsch. Anales del Instituto Nacional de Investigaciones Agraria. Proteccion Vegetal 10: 81-93.

Ms received May 30, 1986

saushuippua. Ensimmäisen muodostivat talvehtineet yksilöt touko- ja kesăkuun vaihteessa ja toisen uuden sukupolven aikuiset heinäkuun lopussa. Kirppojen esiintymisrunsaus viljelyksillä vaihteli paljon, sillă kirpat liikkuivat vain lyhyită matkoja; tăten niiden esiintyminen oli hyvin paikallista. Isot vuotuiset runsausvaihtelut johtuivat lähinnă isăntăkasvitilanteen muutoksista. Tămăn vuoksi oli vaikeata nähdä, vaihteliko kirppojen esiintymisrunsaus alueittain.

Ainoastaan Phyllotreta undulata (Kutsch.) ja P. strio- 
lata (F.) olivat merkittäviă tuholaisia rypsiviljelyksillă. $P$. undulata:n osuus oli $80-90 \%$ ja P. striolata:n n. $10 \%$ kirppojen kokonaismäärästă. $P$. striolata oli yleisempi retiisi- kuin rypsiviljelyksillă. Sokerijuurikasta vioitti ainoastaan Chaetocnema concinna (Marsh). Myös muita kirppalajeja esiintyi vähäisină măărină rypsi-, retiisija sokerijuurikasmailla. Nämă eivăt kuitenkaan aiheuttaneet tuhoja. Imupyydys keräsi văhän kirppoja, mutta se osoitti silti selvästi kirppojen esiintymisajankohdat.
Kirpat aiheuttivat eniten vahinkoa lyhyen sirkkataimivaiheen aikana. Torjunnan kynnysarvo oli tuolloin yksi kirppa/kasvi. Myöhemmin useatkaan kirpat eivăt enäă estäneet kasvua. Kirppojen esiintymisrunsaus oli tutkimuksen aikana niin pieni, että siementen torjunta-ainekuorrutus oli tarpeeton. Syysrypsin viljelyn loppuminen näytti olevan osasyynả kirppojen vähäiseen mảảräăn. Toisaalta tuholaistorjunta rapsikuoriaista vastaan tehoaa myös kirppoihin. 